\title{
THE MECHANISM OF FISCAL POLICY
}

\author{
Lidiia Fedoryshyna'
}

\begin{abstract}
The purpose of this article is to study fiscal policy, which is one of the methods of regulating the country's macroeconomic policy. Theoretical approaches of scientists to the definition of the term "fiscal policy" are investigated. The contents and principles of the functioning of the mechanism of fiscal policy are disclosed. Method. Theoretical approaches to the definition of mechanisms and discrete components of the fiscal policy of the state and its criteria characteristics have been developed. The research has been based on the use of a systematic approach to the consideration of fiscal phenomena, on the fundamental principles of economic theory, systems theory, theory of finance, theory of taxes, etc. Results. It is observed that the budget deficit and the national debt are closely linked: the increase in the budget deficit leads to an increase in the national debt. But the absolute magnitude of the budget deficit, and therefore of the public debt, does not provide enough information for economic analysis. It is necessary to know what processes the budget deficit is serving, what changes in the reproduction cycle it reflects. It is also very important to measure changes in public debt in relation to changes in GDP. In addition, the tax burden is increasing as a result of these changes. Value/originality. It is determined that along with the expected changes in the methodology of calculation and procedure of tax payment, taxpayers are also concerned about the question of changing the tariff grid by the total amount of taxes due in absolute terms and in relation to the volume and resultant indicators of production activity (revenue, profit). An innovative tariff policy has been proposed and opportunities for using non-traditional agricultural insurance products have been revealed. Recommendations to improve the fiscal policy of the state have been made. The conceptual platform for harmonizing the mechanism of fiscal policy regarding economic entities is substantiated.
\end{abstract}

Key words: methodology, analysis, fiscal policy, mechanism, macroeconomic regulation, policies of built-in stabilizers, economic, tax.

JEL Classification: G28, H24, J2O

\section{Introduction}

Welcome to the world of fiscal policy. So, thanks to the good graces of J. M. Keynes it is customary to name an area of the economy that is directly related to the interaction of state bodies and all other business entities. This interaction is achieved through a system of government orders, taxation and transfer payments.

Since the implementation of public spending means the use of state budget funds and taxes are the main source of replenishment, fiscal policy comes down to manipulating the state budget.

Fiscal policy is a very powerful weapon. Some economists argue that like an atomic bomb, it is a too powerful weapon to allow individuals and governments to play with it; so, it would be better if fiscal policy have never been applied. Nevertheless, it is absolutely certain that just as no nation will sit idly by allowing the plague to mow the population, in the same way fiscal policy always comes into play in every country as soon as a depression begins to unfold. There is no other choice than to try to direct fiscal policy in a healthy rather than pernicious direction.

Any government always pursues some fiscal policy regardless of whether it is aware of it or not. The real question is whether this policy will be constructive or whether it will be unconscious and inconsistent.

\section{Economic crisis effects on consumer behavior}

The topic of fiscal policy today is very relevant, since the economy of the republic is not going

\footnotetext{
Corresponding author:

${ }^{1}$ Vinnytsia National Agrarian University, Ukraine.

E-mail: fedorishina@i.ua

ORCID: https://orcid.org/0000-0003-1577-6699

ResearcherID: L-5746-2018
} 
through the best of days and the fate of every person living in our country and the fate of the whole country depends on how the government will implement the fiscal policy. As the surgeon's scalpel heals, cutting off the unnecessary, the government needs to move in such a way as to cut off unnecessary government spending to minimize taxation of business entities, thereby creating the most favorable conditions for business development but at the same time not to deprive transfer payments of those who really need them.

One of the main tools of macroeconomic regulation is fiscal policy. Under fiscal policy the totality of measures taken by government bodies to change public spending and taxation is understood. Its main tasks are: smoothing the fluctuations of the economic cycle, ensuring sustainable economic growth, achieving a high level of employment, reducing inflation.

Fiscal policy, depending on the mechanisms of its regulation for changing the economic situation, is divided into discretionary and automatic fiscal policies (policies of built-in stabilizers).

Discretionary policy is understood as the deliberate manipulation of government spending and taxes. It is also called active fiscal policy. It can be carried out using both direct and indirect tools. The first include a change in government procurement of goods and services, transfer payments. The second includes changes in taxation (tax rates, tax benefits, tax base) accelerated depreciation policy.

Consider the mechanism of discretionary fiscal policy using the Keynesian model of "income expenses" and assuming that:

1) government spending does not affect either consumption or investment;

2) net export is zero;

3 ) the price level is constant;

4) initially, there are no taxes in the economy;

5) fiscal policy has an impact on total costs (aggregate demand) but not on aggregate supply.

Given these assumptions we analyze the impact of changes in government spending on the volume of national production (output), income.

\section{Differences in consumer spending behaviour among age groups}

In practice the level of government spending and tax revenues can change even if the government does not take appropriate decisions. This is due to the existence of built-in stability which defines an automatic (passive, non-discretionary) fiscal policy. Built-in stability is based on mechanisms that operate in self-regulation mode and automatically respond to changes in the state of the economy. They are called built-in (automatic) stabilizers. These include:

1. Changes in tax revenue. The amount of taxes depends on the income of the population and enterprises. In a period of decline in production, revenues will begin to decrease which will automatically reduce tax revenues to the treasury. Consequently the income remaining in the population and enterprises will increase. This will to some extent slow down the decline in aggregate demand which will positively affect the development of the economy. The progressiveness of the tax system has the same effect. With a decrease in the volume of national production, incomes decrease but at the same time tax rates decrease, which is accompanied by a decrease in both the absolute amount of tax revenues to the treasury and their share in the company's income. As a result, the fall in aggregate demand will be milder.

2. Unemployment benefit systems and social benefits. They also have automatic countercyclical effects. Thus an increase in the level of employment leads to an increase in taxes which finance unemployment benefits. With a decline in production the number of unemployed increases which reduces aggregate demand. However at the same time the amount of unemployment benefits is also growing. This supports consumption, slows the decline in demand and therefore counteracts the growing crisis. In the same automatic mode the systems of income indexation and social payments function. There are other forms of built-in stabilizers: farmer assistance programs, corporate savings, personal savings, etc.

Built-in stabilizers mitigate changes in aggregate demand and thereby help stabilize national output. It is thanks to their action that the development of the economic cycle has changed: the decline in production has become less deep and shorter. Previously this was not possible since tax rates were lower and unemployment benefits and social benefits were negligible.

The main advantage of a non-discretionary fiscal policy is that its instruments (built-in stabilizers) turn on immediately at the slightest change in economic conditions, there is practically no time lag.

The disadvantage of automatic fiscal policy is that it only helps smooth out cyclical fluctuations but cannot eliminate them. It should be noted that the 
higher the tax rate, the higher the transfer payments, the more effective the non-discretionary policy.

\section{Findings}

Depending on the purpose, a stimulating or restraining fiscal policy is pursued. In periods of decline in production, it is necessary to increase government spending, reduce taxes or do both, pursue a stimulating (expansionist) policy. In the short term, it softens the business cycle. In the short term, it softens the business cycle. In the long term tax cuts can lead to economic growth. This was the case in the 1980s in developed countries where tax reforms, as a result of which corporate income tax and income tax rates were reduced, helped boost the economy.

In order to reduce inflation, they are implementing a restraining (restrictionist) fiscal policy. It consists in cutting government spending, increasing taxes or in a combination of both. In the short term restraint policies reduce aggregate demand and thereby help reduce demand inflation. In the long term it can lead to a decline in production and an increase in unemployment.

A change in the full employment budget shows how the current fiscal policy affects the change in aggregate demand. An increase in the deficit or a reduction in the surplus of the full-employment budget indicates a stimulating fiscal policy aimed at expanding aggregate demand. On the contrary, a reduction in the deficit or an increase in the surplus of the full employment budget is the result of the implementation of a restraining fiscal policy the aim of which is to reduce aggregate demand.

According to the Keynesian approach the use of taxes as an important tool of fiscal policy can stimulate business and investment activity, since tax cuts leave at the disposal of entrepreneurs a much larger portion of money than the amount of tax cuts.

However, this provision applies only to proportionate taxes. They play the role of automatic stabilizers of the economy.

\section{Conclusions}

Fiscal policy is one of the main tools of macroeconomic regulation.

1. Fiscal policy, depending on the mechanisms of its regulation for changing the economic situation, is divided into discretionary and automatic fiscal policies (policies of built-in stabilizers).
Discretionary policy is understood as the deliberate manipulation of government spending and taxes. It is also called active fiscal policy. In practice the level of government spending and tax revenues can change even if the government does not take appropriate decisions. This is due to the existence of built-in stability, which defines an automatic (passive, non-discretionary) fiscal policy.

2. The most significant fiscal instruments are taxes and government procurement. In periods of decline in production it is necessary to increase government spending, reduce taxes or do both and etc. pursue a stimulating (expansionist) policy. In order to reduce inflation they are implementing a restraining (restrictionist) fiscal policy. It consists in cutting government spending, increasing taxes or in a combination of both.

3. One of the important tools to influence the rate of economic growth and consequently, the unemployment rate is the financial including tax system. Among the instruments of financial regulation of the economy a special place is given to government spending and taxes. Taxes perform not only a fiscal but also an economic function. The fiscal function of taxes is to generate cash income from the state. Being the most important lever of influence on socio-economic processes taxes at the same time provide the bulk of the revenue of the state budget. Direct taxes, being proportional, have a direct impact on the dynamics of GDP and are related to automatic (built-in) stabilizers of the economy. Local taxes, which occupy a significant share in the structure of the budget revenues, emphasize the fiscal nature of the tax system.

4. The tax system of any country is effective if it is formed on common methodological approaches that take into account the solvency of the population, tax benefits for the strategic goals of the economy an even distribution of taxes among business entities, the optimal tax burden, etc. An important element of the tax policy of the state are the criteria for taxation. Economists call justice (equality) as the first criterion, and efficiency as the second criterion. The first criterion is based on the fact that state taxes and their spending affect the distribution of income in society, placing burdens on some and providing benefits to others. Society ultimately strives for a fair distribution of these burdens and benefits.

But the main criterion in the tax system is still the solvency criterion. In accordance with it, taxes 
should increase as income rises, since as a result of this inequality in material conditions is reduced. Such a tax system is called progressive. On the contrary if after paying taxes, inequality in society increases there is a regressive tax system. According to the Keynesian approach the use of taxes as an important tool of fiscal policy can stimulate business and investment activity, since tax cuts leave at the disposal of entrepreneurs a much larger portion of the money than the amount of tax cuts.

The state does not limit its intervention in the economy only by varying tax rates. The goals of state policy may be to ensure the equalization of incomes of citizens, support of socially significant industries with subsidies and investments, stimulate small business, net exports and stabilize the economy. In this regard, the state will carry out certain expenses from the state treasury.

5. Due to the multiplier effect each unit of the reduction of the proportional tax accounts for much more units of GDP growth.

6. Discretionary and non-discretionary fiscal policies are applied in combination, depending on the current dynamics of GDP. Discretionary policy has an effect in the short run.

7. According to the Keynesian concept of fiscal policy the budget deficit as a rule, increases during a recession and decreases during periods of recovery and economic recovery. At the same time, economic stabilization and GDP growth are not always ensured. If the growth of government spending is financed by an increase in income taxes, then the final increase in the national product is equal to the initial increase in government spending.

8. According to the classical concept, fiscal policy is considered only as an instrument of financial support for the government to fulfill its functions, but not as a stabilization policy. The classic concept is based on the Ricardian equivalence, according to which the fiscal impact will not cause a change in the value of GDP but the redistribution of funds between the private and public sectors due to the effect of the "crowding out" effect when money is neutral.

9. The state budget is an estimate of state revenues and expenditures for a certain period, most often for a year, drawn up with an indication of the sources of state revenues and areas of expenditure. The budget has revenues and expenditures, which should be balanced in the planned future.

The role of the budget in the national economy is significant. It is part of the finances of a country controlled by the state, therefore, with the help of the budget, the state is able to intervene in market mechanisms.

Secondly, the budget is a way of accumulating funds to solve large, global economic problems.

Thirdly, the availability of the budget allows solving complex social problems (poverty, unemployment, hunger, literacy, health of the nation, etc.).

10. There are three ways to finance the budget deficit:

- By additional issue of money;

- Due to loans of the Central Bank;

- By borrowing from the public and firms.

The budget deficit and public debt are closely related: the increase in the budget deficit leads to an increase in public debt. However, the absolute magnitude of the budget deficit and therefore of public debt is not indicative of economic analysis. It is necessary to know what processes the budget deficit serves, what changes in the reproductive cycle it reflects. In addition, it is very important to measure changes in public debt in relation to changes in GDP.

Government debt often shows the level of financial stability of the economy. Since public debt affects the future tax burden, over the past decades, many scientists are trying to formulate various methodological approaches to choosing ways to reduce it. Three main concepts of budget deficit regulation can be distinguished:

- annual balancing;

- cyclic balancing;

- functional balancing.

There is a number of objections regarding the effectiveness of fiscal measures in the economy. According to the classical concept, fiscal policy is considered only as an instrument of financial support for the government to fulfill its functions but not as a stabilization policy.

The classical concept is based on Ricardian equivalence, according to which the fiscal effect will not cause a change in the value of GDP but a redistribution of funds between the private and public sectors due to the effect of the "crowding out" when money is neutral.

11. Changes in the fiscal sphere and fiscal policy play a key role in the economic development of the country and the implementation of an effective economic policy.

Through structural reforms of the tax and budget systems in the Republic of Belarus, the following main tasks are implemented: 
- Financial support for the fulfillment by the state of its functions and obligations;

- Maintaining financial stability in the country;

- Reducing the negative effects of taxes, inefficient government spending and debt on sustainable social and economic development;

- Ensuring the financial integrity of the state.

Over the past years, significant progress has been achieved in building a budget system in the Republic of Belarus that meets modern requirements. In fact, it underwent a transformation from administrativecommand mechanisms to redistribute all public resources to a combination of a tax system based on market principles and budget expenditures, which mainly ensure the functioning of the state social protection system, budgetary organizations and the public sector of the economy.

Direct subsidies to the non-state sector play an insignificant role (however it should be borne in mind that this is largely due to the slower pace of privatization of state property).

A system of public procurement is being developed on a competitive basis. A generally accepted classification of budget revenues and expenditures (including economic), as well as sources of internal and external financing of the budget deficit and types of public debt, has been introduced.

\section{References:}

Aleskerova, Yu., Mulyk, T., \& Fedoryshyna, L. (2018). Improving credit protection analysis methods Reports of main agricultural enterprises. Baltic Journal of Economic Studies, vol. 4, no. 2, pp. 1-7. doi: $10.30525 / 2256-0742 / 2018-4-2-1-7$

Aleskerova, Yu., \& Fedoryshyna, L. (2018). Analysis of investment activities of enterprises of Ukraine. Economic system development trends: the experience of countries of Eastern Europe and prospects of Ukraine.

Aleskerova, Yu., Fedoryshyna, L., \& Koval, N. (2018). Features of loan security for the reproduction of fixed assets for agricultural purposes. Baltic Journal of Economic Studies, vol. 4, no. 4, pp. 1-5. doi: $10.30525 / 2256-0742 / 2018-4-4-1-5$

Aleskerova, Y., Kovalenko, L., \& Havryliuk, V. (2019). Innovative financial criteria for methodological approaches to the assessment of agrarian insurance. Baltic Journal of Economic Studies, vol. 5, no. 4, pp. 34-41. doi: 10.30525/2256-0742/2019-5-4-34-41

Rogach, S., Vdovenko, L., \& Polishchuk, O. (2019). Agriculture of Ukraine under the joint policy of the European Union. Baltic Journal of Economic Studies, vol. 5, no. 3, pp. 178-183. doi: 10.30525/22560742/2019-5-3-178-183

Plakhtii, T., Fedoryshyna, L., \& Tomchuk, O. (2019). Socio-economic component of preferential taxation of individuals' incomes. Baltic Journal of Economic Studies, vol. 5, no. 2, pp. 171-175. doi: 10.30525/2256-0742/2019-5-2-171-175

Koval, N., Priamuhina, N., \& Zhmurko, I. (2020). Analyz economic - financial experience of the world countries in the system of pension insurance. Baltic Journal of Economic Studies, vol. 6, no. 1, pp. 1-7. doi: 10.30525/2256-0742/2020-6-1-1-8

Kritzer, B. E. (1996). Privatizing social security: the Chilean experience. Social Security Bulletin, no. 3, pp. 45-55.

Kubicek (2005). Contribution rates to funded pension systems in the new member countries. Research in International Business and Finance, vol. 19, issue 2, pp. 266-280.

Bettendorf, Leon J.H. \& Heijdra, Ben J. (2005). Population ageing and pension reform in a small open economy with non-traded goods. Journal of Economic Dynamics Control, no. 6, pp. 265-290.

Nicoholas George (2002). Sweden's savers are kept pasted on state of their funds. Financial Times. 2002. March 25, p. 7.

Oskar Cerrangolo (2003). Pension Reform in Latin America. Conference on «Privatisation of Public Pension Systems - Forces, Experience, Prospects». Vienna, 2003. June 19-21, pp. 256-275.

Palmer Edvard (1998). The Swedish Pension Reform Model - Framework and Issues. The national Social Insurance Board, May. 32 p. 